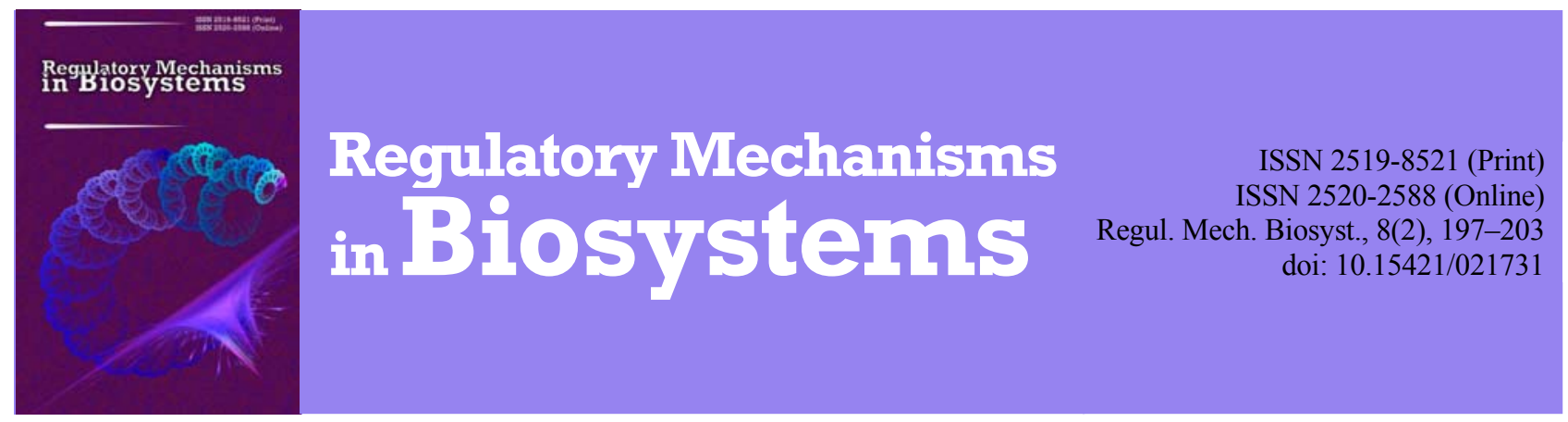

\title{
Myofascial syndrome as a pathogenetic mechanism for formation of scoliosis in people with multiple sclerosis
}

\author{
Y. Lysenko \\ Precarpatian National University named after Vasyl'Stefanyk, Ivano-Frankivsk, Ukraine
}

Article info

Received 24.03.2017

Received in revised form 20.04.2017

Accepted 23.04.2017

Precarpatian National University named after Vasyl' Stefanyk, Shevchenko Str., 57 ,

Ivano-Frankivsk, 76018, Ukraine.

Tel.: +38-066-07-12-052.

E-mail: uristOO@mail.ru
Lysenko, $Y$. (2017). Myofascial syndrome as a pathogenetic mechanism for formation of scoliosis in people with multiple sclerosis. Regulatory Mechanisms in Biosystems, 8(2), 197-203. doi:10.15421/021731

The purpose of this research was to conduct a comprehensive analysis of clinical changes and electroneuromyographic indices in people with multiple sclerosis in combination with various types of functional disorders of posture. The study involved 105 people with multiple sclerosis aged 26-58 who were undergoing rehabilitation at a specialized medical center. The degree of spasticity of the muscles was determined by the modified Ashworth scale. To assess the intensity and nature of pain, a neurologic examination was performed using a visual analogue scale and a McGilovsky pain questionnaire. Interference and stimulation electroneuromyography was used to characterize the functional state of the peripheral neuromotor apparatus of skeletal muscles, the results of which determined the maximum arbitrary contraction of the muscle using quantitative analysis of time, amplitude and frequency parameters, and also determined the speed of the pulse, the amplitude and duration of the $\mathrm{F}$ wave, latent period and polyphase $\mathrm{M}$-wave, monosynaptic testing (H-reflex) was carried out. The percentage of $\mathrm{H}_{\max } / \mathrm{M}_{\max }$ was calculated from the electroneuromyographic results. By the ratio between the maximum and minimum amplitude of the M-response, the number of motor units was calculated. To analyze the denervation-reinvational processes of motor units and degenerativerestorative changes in the muscle fibers, spontaneous fibrillation potentials and positive acute waves were recorded. By the stage of manifestation of pain myofascial syndrome, all patients were divided into three groups, in which the force characteristics decreased by $10.2 \%, 25.0 \%$ and $30.2 \%$, respectively. It is well understood in clinic-instrumental research, that in $67.3 \%$ cases of multiple sclerosis the patient also suffers from functional scoliosis. This pathological symptom complex contributes to the creation of not only muscular, but also fascial-ligamental trigger points. They, in turn, are the source of the formation of secondary trigger loci. In terms of the degree of manifestation of subjective pain in the presence of myo-fascial syndrome, all patients were divided into three groups, and depending on the value of individual indicators, three stages of spontaneous fibrillation potentials were identified that clearly correlate with the degree of fibromyalgic syndrome and manifest specific electroneuromyographic disorders in each of these stages. The main pathogenetic mechanism that contributes to the formation of pathological bends of the spine in people with multiple sclerosis is a painful muscular-fascial syndrome. It is provoked by myofascial hypertonia and takes part in the development of cross syndromes, which is also manifested by clear changes in electroneuromyographic parameters in the form of asymmetric muscle tone. This article discusses clinical variants of the course of local muscular-tonic syndromes. Pathogenetic approaches to the prevention of posture disorders in patients with multiple sclerosis are presented here.

Keywords: multiple sclerosis; myofascial syndrome; pain; posture; scoliosis; electroneuromiography

\section{Міофасціальний синдром як патогенетичний механізм формування сколіозу в людей із розсіяним склерозом}

\author{
Ю. Лисенко
}

\section{Прикарпатський національний університет імені Василя Стефаника, Івано-Франківськ, Україна}

\footnotetext{
Проаналізовано клінічні зміни та електронейроміографічні показники людей із розсіяним склерозом у комплексі з різними видами функціональних порушень постави. У дослідженні брали участь 105 людей із розсіяним склерозом віком 26-58 років, які проходять реабілітацію у спеціалізованому медичному центрі. Під час клініко-інструментального дослідження встановлено, що у пацієнтів із розсіяним склерозом у 67,3\% випадків спостерігаються функціональні порушення постави. Цей патологічний симптомокомплекс сприяє створенню не тільки м'язових, а й фасціально-зв'язкових тригерних пунктів. Вони, у свою чергу, стають джерелом формування вторинних тригерних локусів. За ступенем прояву суб'єктивних больових відчуттів за наявності міофасціального синдрому всі пацієнти поділені на три групи, а залежно від величини окремих показників виділено три стадії формування спонтанних потенціалів фібриляцій, які чітко корелюють зі ступенем фіброміалгічного синдрому, що проявляється специфічними електронейроміографічними порушеннями в кожній із цих стадій. Основний патогенетичний механізм, який сприяє формуванню патологічних згинів хребта у людей із розсіяним склерозом, -
} 
больовий м'язово-фасціальний синдром. Він провокується міофасціальним гіпертонусом і бере участь у розвитку перехресних синдромів, що також проявляється чіткими змінами електронейроміографічних показників у вигляді асиметричного м’язового тонусу. У статті обговорюються клінічні варіанти перебігу локальних м’язово-тонічних синдромів. Обгрунтовано патогенетичні підходи до профілактики порушень постави у пацієнтів із розсіяним склерозом.

Ключові слова: розсіяний склероз; міофасціальний синдром; біль; постава; сколіоз; електронейроміографія

\section{Вступ}

Розсіяний склероз - хронічна нейродегенераторна хвороба центральної нервової системи, за якої відбувається вогнищева демієлінізація нервової тканини, що стає причиною неправильної передачі імпульсів уздовж нервових волокон у головному та спинному мозку (Hsieh et al., 2011). Ця хвороба має багатофазовий перебіг із періодами загострень, які стають однією із причин інвалідності серед молодих людей (до 40 років) $\mathrm{i}$ зустрічаються, як правило, частіше у жінок, ніж у чоловіків. Захворюваність коливається від 30 до 100 на 100 тис. населення (Hutchinson, 2013).

Серед багатьох вогнищевих симптомів найчастіше виявляються порушення моторики, чутливості (парестезії), мозочкові (порушення рівноваги) та зорові розлади, порушення діяльності вегетативної нервової системи, больові синдроми, а також психічні дисфункції - порушення когнітивних функцій (Hilz, 2016). Як правило, спочатку хворий починає відчувати ослаблення ізольованих м'язових груп, а пізніше з'являється підвищений м'язовий тонус (спастичність), який ускладнює виконання окремих рухів, іноді робить їх навіть цілком неможливими (Miller, 2013).

За сучасними даними медичної статистики, лідерство у різноманітних проявах розсіяного склерозу тримає гострий і хронічний біль (Dommerholt and Bron, 2013). За даними Henriksson (2013), клінічні прояви больових м'язових тригерних пунктів спостерігаються у 85,9\% пацієнтів із даною патологією, а терапевтичні ефекти від методів і засобів їх лікування не викликають зменшення частоти їх рецидивів.

Останніми роками, базуючись на накопичених фактах, сформульовано чітку теорію генераторних систем. За цією теорією, основа патологічного болю - створення в центральній нервовій системі генератора патологічно посиленого збудження (сукупності гіперактивних нейронів). Ця гіперактивація (розгальмовування) нейронів і утворення генератора можливі із залученням синаптичного чи несинаптичного механізмів. Тривало існуючий генератор, по-перше, закріпляє свою структуру у вигляді нейропластичних змін, а, по-друге, чинить патологічний вплив на інші структури ноніцептивної системи, захоплюючи їх у патологічну больову систему. Клінічно больовий синдром проявляється тільки тоді, коли у патологічну больову систему включається соматосенсорна та орбітофронтальна кора головного мозку. Обов'язкова умова формування генератора патологічної больової системи - слабкість гальмівних систем, тобто антиальгічної системи, яка, за даними Suputtitada (2016), страждає за розсіяного склерозу.

При цьому окремі автори (Colbert and Borg-Stein, 2016) вказують, що больові відчуття найбільше виявляються у молодому та середньому віці (в основному до 50 років). Із збільшенням віку спостерігається збільшення проявів не стільки больових відчуттів, скільки обмеження рухливості, особливо за рахунок зменшення гнучкості (Hutchinson, 2014). Хронічний біль і зменшення рухової активності - ланки одного патологічного кола, яке має дезадаптивне значення для організму людини з розсіяним склерозом. Через зниження гнучкості розвиваються різні порушення з боку м'язової системи, що проявляється у вигляді асиметрії та дистонії основних груп м'язів. Це, у свою чергу, викликає порушення постави внаслідок недосконалості «м'язового корсета».

За даними різних авторів, розсіяний склероз іноді супроводжується функціональними порушеннями постави різного ступеня вираженості. Це - несприятливе ускладнення, яке значно знижує рівень ефективності лікувально-реабілітаційних заходів у таких пацієнтів (Roeing et al., 2017). Якщо ознаки функціонального порушення постави тривають більше одного року, воно може створити всі умови для виникнення більш грізного ускладнення - сколіозу, який проявляється комплексом дегенеративно-дистрофічних змін у складових хребта (Hutchinson, 2014). Дегенеративно-дистрофічні зміни хребта викликають специфічний больовий синдром, у реалізації якого переважно задіяні м'язи, фасції та зв'язки, тому він отримав назву м'язово-фасціальний синдром (Colbert and Borg-Stein, 2016). Тригерна точка цього синдрому - міофасціальний гіпертонус (Hilz, 2016). Однак роль кожного 3 них у загальній структурі больового м'язово-фасціального синдрому за розсіяного склерозу залишається маловивченою.

Недосконалість або патологія аферентної частини багатьох аналізаторів спричинює формування патологічної постави, оскільки відсутня інформаційна база для формування повноцінної фізіологічної функціональної системи (Pandey et al., 2014). У людей із розсіяним склерозом функціональні порушення постави чи патологічні форми хребта формуються пришвидшеними темпами та спостерігаються у багатьох випадках уже на ранніх етапах перебігу цього захворювання (Miller, 2013). Незважаючи на значну кількість досліджень, праці щодо вивчення вертебрологічної патології в людей із розсіяним склерозом поодинокі, а результати таких досліджень фрагментарні, вимагають узагальнення (Kanekar and Aruin, 2013). Поряд із цим вимагають своєї інтерпретації електронейроміографічні показники за функціональних порушень постави чи вираженої патології хребта у людей із розсіяним склерозом (Partanen et al., 2010).

Мета цієї статті - проаналізувати клінічні зміни та електронейроміографічні показники в людей із розсіяним склерозом із функціональними порушеннями постави.

\section{Матеріал і методи досліджень}

Обстежено 105 людей із розсіяним склерозом, віком 2658 років, які проходять реабілітацію у спеціалізованому центрі (м. Славськ, Польща). Ступінь спастичності м'язів визначали за модифікованою шкалою Ашворта, що дозволяє виявити порушення різного ступеня $(1,1+, 2,3)$ за суб'єктивно-об'єктивними ознаками, які проявляються підвищенням м'язового тонусу чи опором м'язів залежно від відсотка можливої амплітуди рухів у суглобах і характеру утруднення цих рухів під час пасивних рухів (Hutchinson, 2013). Для встановлення давності захворювання проаналізовано медичні картки.

Проведено неврологічне обстеження всіх пацієнтів із використанням тестів оцінювання інтенсивності та характеру болю (візуально-аналогова шкала та опитувальник болю МакГіловського). Крім цього проведено обстеження обсягу рухових функцій, м'язового тонусу, чутливих порушень (шкала стану функціональних систем Курцке Disability Status Scale, Functional System Score, шкала неврологічного дефіциту, шкала ADL).

Ступінь прояву міофасціального больового синдрому діагностували методом пальпації за схемою, запропонованою Simons and Dommemolt (2007).

Для характеристики функціонального стану периферичного нейромоторного апарату скелетних м'язів використано стимуляційну та інтерференційну електронейроміографію, яку проведено на комп'ютерному електронейроміографічному комплексі «Нейро-ЕМГ-Мікро» виробництва фірми «Нейрософт» (Росія), який має низький рівень шумів, високу чутливість (10-500 мкВ/см) та стійкість до спотворень. 
Досліджували максимальне довільне скорочення м'яза 3 використанням кількісного аналізу часових, амплітудних і частотних параметрів. Визначали швидкість проведення імпульсу, амплітуду та тривалість F-хвилі, амплітуду, латентний період i поліфазність М-хвилі, проводили моносинаптичне тестування (Н-рефлекс). За електронейроміографічними результатами розраховували відсоток співвідношення $\mathrm{H}_{\max } / \mathrm{M}_{\max }$. За співвідношенням між максимальною та мінімальною амплітудою М-відповіді розраховували кількість рухових одиниць (РО). Для аналізу денерваційно-реінерваційних процесів рухових одиниць і дегенеративно-відновних змін у м'язових волокнах реєстрували спонтанні потенціали фібриляцій і позитивні гострі хвилі.

Максимальну швидкість проведення імпульсу (ШПІ) по нервових волокнах визначали за формулою: $\frac{\mathrm{S}}{\mathrm{t}_{2}-\mathrm{t}_{1}}, \mathrm{~m} / \mathrm{c}$, де $\mathrm{t}_{1}-$ латентний період у разі подразнення нерва в дистальній точці (c), $\mathrm{t}_{2}$ - латентний період при подразненні нерва в проксимальній точці (c), S - відстань між проксимальною та дистальною точками стимуляції (м).

Статистичне опрацювання результатів електронейроміографічних досліджень здійснювали за допомогою програмного пакета GrafPad Prism 4.0 (GrafPad Sowtware Inc., США).

\section{Результати}

Аналіз медичних карток свідчив, що за давністю захворювання всі пацієнти спеціалізованого реабілітаційного центру розподілені таким чином: до 5 років - 15 хворих (17,6\%), до 10 - 36 (42,6\%), до 15 - 30 (35,2\%), понад 15 років - 4 (4,7\%). За симптоматикою: порушення черепних нервів (крім II пари) домінували у 10 (8,5\%) хворих, симптоми ураження пірамідного шляху - у 38 (32,3\%), порушення координації - у 18 (15,3\%), порушення чутливості - у 19 (16,2\%).

Дані клініко-антропометричного дослідження вказують на наявність у 67,6\% пацієнтів із розсіяним склерозом функціональних порушень постави. У таких пацієнтів визначаються значно вищий ступінь болю у поперековому відділі хребта, шиї та грудній клітці.

За ступенем прояву больового міофасціального синдрому всі пацієнти поділені на три групи.

Першу групу складають 31,6\% пацієнтів, у яких спостерігаються вогнищеві болі, що проявляються тільки за активної локомоції. Ці болі провокуються надавлюванням або розтягуванням, в основному, довгих м'язів спини, консистенція яких має локальні м'язові ущільнення. При цьому поперечна пальпація цих м'язів не супроводжується локальною спастичною відповіддю, а силові характеристики залишаються без змін.

До другої групи увійшли 47,3\% пацієнтів, у яких спостерігаються спонтанні тягнучо-ниючі болі в усьому м'язі. До його складу входить активний тригерний пункт із регіонарною м'язовою тонічною реакцією. Ці явища відбуваються у м'язах-синергістах. Під час пальпації у поперечному напрямку виявляються шкірні гіпералгічні зони, що викликають локальний спазм. Порівняно з м'язами контрлатеральної сторони силові характеристики зменшуються на $25,0 \%(\mathrm{P}<0,05)$.

Третя група (21,1\% пацієнтів) характеризується вираженими дифузними болями, що виникають під час як активних, так і пасивних рухів і характерні для м'язів антагоністів і синергістів. Біль при цьому визначається активним тригерним пунктом із генералізованою м'язово-тонічною реакцією. Сила м'язів знижується на $30,2 \%(\mathrm{P}<0,05)$.

У результаті пальпаторного обстеження м'язів спини та зон больової реакції в усіх обстежених пацієнтів виявлено активні тригерні пункти, які більшою мірою превалювали у м'язах поперекового відділу хребта (табл.). Для пацієнтів із функціональними порушеннями постави та хворих без такого порушення зареєстровано вірогідну $(\mathrm{P}<0,05)$ різницю за відносною кількістю хворих із рівнем напруження м'язів величиною в 1 бал (на 8,2\%) і 3 бали (на 8,6\%) за майже рівної кількості хворих із величиною напруження м'язів у 2 бали (різниця невірогідна, складає тільки $0,4 \%, \mathrm{P}>0,05$ ).

Чим вища вираженість больових відчуттів, тим частіше тригерні пункти формуються у додаткових анатомічних утвореннях, зокрема у зв'язках і фасціях. При цьому основні скарги людей першої групи зводяться до локального болю на проблемному боці функціонального порушення постави, яка має місцевий прояв і виникає під час розтягування та місцевого натискання. В останньому випадку біль зникає після незначного розтягування.

\section{Таблиця}

Міофасціальні тригерні пункти та ступінь напруження м'язів у хворих на розсіяний склероз залежно від наявності функціональних порушень постави

\begin{tabular}{|c|c|c|c|c|}
\hline \multirow[b]{2}{*}{ Показник } & \multicolumn{4}{|c|}{ Кількість тригерних пунктів } \\
\hline & \multicolumn{2}{|c|}{$\begin{array}{c}\text { пацієнти з функціо- } \\
\text { нальними порушеннями } \\
\text { постави, } \mathrm{n}=71 \\
\end{array}$} & \multicolumn{2}{|c|}{$\begin{array}{c}\text { пацієнти без } \\
\text { порушень постави, } \\
\text { n=34 }\end{array}$} \\
\hline \multirow{3}{*}{$\begin{array}{l}\text { Міофасціальні } \\
\text { тригерні пункти }\end{array}$} & абс. & $\%$ & абс. & $\%$ \\
\hline & 71 & 100 & 34 & 100 \\
\hline & \multicolumn{4}{|c|}{ Ступінь напруження м'язів } \\
\hline 1 бал & 5 & 7,2 & 5 & $15,4^{*}$ \\
\hline 2 бали & 39 & 54,9 & 19 & 55,3 \\
\hline 3 бали & 27 & 37,9 & 10 & $29,3 *$ \\
\hline
\end{tabular}

Примітка: *- ${ }^{*}<0,05$ порівняно 3 І групою.

У людей другої групи крім локальної болючості визначаються локальні ущільнення м'язів, спостерігається активний міогенний тригерний пункт. Він характеризується спонтанною та відображеною (ексвізитною) болючістю, локальною спастичною відповіддю, зміною координаційних співвідношень у вигляді синергічних рухів і дестабілізації реципрокних взаємовідношень.

В обстежених третьої групи під час глибокої, проникаючої ковзкої пальпації в ділянці локальної болючості спостерігаються твердіші ділянки, які практично не деформуються під час натискання та розтягування.

Результати обстеження хворих за модифікованою шкалою Ашворта показали, що всі ступені спастичності м'язів виявляються майже з однаковою частотою в усіх пацієнтів. При цьому перший ступінь визначається у 19,0\% хворих, ступінь $1+$ у вигляді легкого підвищення м'язового тонусу та мінімального опору м'язів у половині цілої амплітуди руху виявляється також у 19,0\% пацієнтів, ступінь 2, що проявляється помірним підвищенням м'язового тонусу протягом усього об' єму чи діапазону можливого для даного суглоба руху на фоні неутруднених пасивних рухів установлено у $24,0 \%$ усіх обстежених, ступінь 3 у вигляді значного підвищення м'язового тонусу та утруднених пасивних рухів спостерігається ще у 19,0\% випадків. На цьому фоні у $81,0 \%$ хворих із геміпарезами виявлено вторинний міофасціальний больовий синдром.

При цьому зниження м'язової сили четвертого ступеня за шкалою Lovetta виявлено у 21,0\% осіб, третього - у 22,0\% пацієнтів, другого - у 38,0\% хворих.

У цих людей нерідко спостерігається надлишкове поєднане залучення у скоротливу активність ближніх і віддалених агоністів, що проявляється регіонарними м'язово-тонічними реакціями, які не мають пристосувального значення.

Наведені дані, а також відсутність об'єктивних критеріїв, що визначають формування міофасціального гіпертонусу спонукали нас до проведення електронейроміографічного обстеження. У результаті встановлено, що у людей першої групи спостерігаються потенціали занурення (тобто під час уведення голкового електрода), які тривають понад 10 с. Розподіл діаграми потенціалу дії рухової одиниці за тривалістю характеризується нормальними значеннями у 76,4\% (від загальної кількості) у зоні тривалості 6-10 мс. При цьому у $12,5 \%$ випадків вони мають вкорочені (менше 5 мс) і в $11,1 \%$ - подовжені (понад 10 мс) потенціали (рис. 1). 
У пацієнтів другої групи поряд із потенціалами занурення характер діаграм потенціалу дії рухової одиниці характеризується розподілом на рівні 50,0\% загальної кількості у зоні потенціалів тривалістю 6-10 мс, 20,1\% - вкорочених і 29,9\% подовжених.

У хворих третьої групи розподіл діаграм характеризується пропорційним розподілом потенціалу дії рухової одиниці: 50,0\% у зоні середньої тривалості, по 25,0\% - у зоні вкорочених і тривалих потенціалів. Крім того, у третій групі спостерігається «залпова» електроміографічна активність під час поперечної пальпації м'язів. Результати такого розподілу підтверджують дані нашого обстеження, які вказують на різке зниження активності окремих частин опорно-рухового апарату для забезпечення найпростіших і найнадійніших характеристик локомоцій, які спостерігаються в усіх пацієнтів із розсіяним склерозом у вигляді патологічних рефлекторних реакцій (34,6\% випадків), підтримання гіпертонусу (76,1\%), порушення силових характеристик м'язів (89,2\%), реципрокних відношень (45,3\%), синергізму та антагонізму цілих груп скелетних м'язів (відповідно у $23,7 \%$ та $27,8 \%$ паціентів).

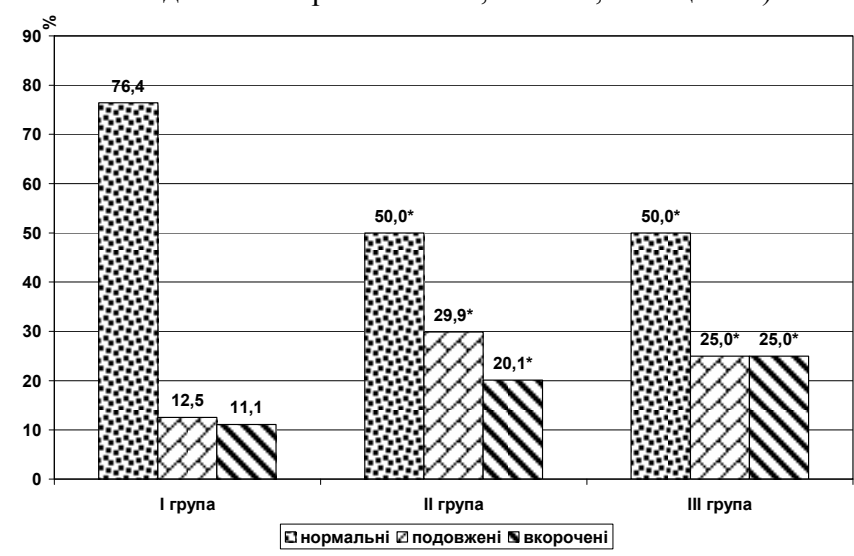

Рис. 1. Розподіл потенціалу дії рухової одиниці у різних групах людей із розсіяним склерозом залежно від ступеня прояву больового міофасціального синдрому: * $-\mathrm{P}<0,05$ порівняно $з$ першою групою

Залежно від величини показників електронейроміографії виділено три стадії формування спонтанних потенціалів фібриляцій:

- на першій стадії визначаються дисфункція корекційної побудови локомоцій, що реалізується у вигляді локальних м'язових і фасціальних гіпертонусів тих груп м'язів, які розташовані на контрлатеральному боці від патологічного згину хребта;

- на другій стадії змінюється стереотип рухів, з'являються тонічні порушення, пов'язані $з$ порушенням постави, що супроводжується генералізованими, регіонарними, перехресними або пошаровими синдромами;

- для третьої стадії характерне збільшення детермінації міофасціального гіпертонусу за рахунок участі супрасегментарних центрів вегетативної нервової системи, що проявляється індивідуальними порушеннями вегетативного тонусу (у 48,2\% пацієнтів), дестабілізацією сну (у 79,3\%), депресивними реакціями (83,1\% випадків).

Формування психовегетативного синдрому за поєднаної патології (РС + сколіоз + плоскостопість) відбувається нерівномірно (у різних пацієнтів від 1,0 до 2,5 року). Однак за наявності сформованого фіброміалгічного компонента (протягом 3-6 місяців) функціональний дефіцит протибольової системи сприяє його пришвидшеному формуванню у $35,7 \%$ пацієнтів.

Залежно від цього ми виділяємо три ступені фіброміалгічного синдрому:

1) легкий ступінь виражається активацією тригерних феноменів у вигляді локальної болючості, ущільненням і судомами (як відповідь на міофасціальні гіпертонуси, у 46,2\% пацієнтів), що проявляються вкороченням і гіпотонічністю м'язів, місцевими полімоторними реакціями, гіпергідрозом шкіри. У цій стадії спостерігаються синдроми переднього драбинчастого, грушоподібного, малого грудного, великого та малого заднього прямих м'язів голови та розгиначів спини (рис. 2);

2) середній ступінь характеризується певними електронейроміографічними порушеннями (рис. 3) та приєднанням порушення рухового стереотипу, а вторинний синдром вегетативної дисфункції може бути перманентним або пароксизмальним у формі астенії (27,2\% паціснтів), звуження діапазону вегетативного реагування (33,2\% пацієнтів), перехресних синдромів (27,8\% випадків), незначними змінами постави (від $15,3 \%$ до $37,9 \%$ обстежених хворих), зниження рухливості під час виконання складних рухових комплексів. Зранку у 75,6\% таких пацієнтів $\epsilon$ скарги на тугорухомість і ломоту в усьому тілі, які проходять після розминки;

3) важкий ступінь характеризується вираженими електронейроміографічними порушеннями у вигляді асиметричного тонусу м'язів-розгиначів тулуба (рис. 4) та сформованими перехресними синдромами.

У таких пацієнтів формується специфічний тип локомоторної організації, яка характеризується незграбністю рухів, невмінням розслаблятися, вони погано повторюють фізичні вправи, передбачені реабілітаційною програмою. У 83,4\% цих хворих виявлено виражений шийний гіперлордоз, сутулість, плечі припідняті, медіальний край лопатки висувається допереду, нерідко виявляється також поперековий гіперлордоз.

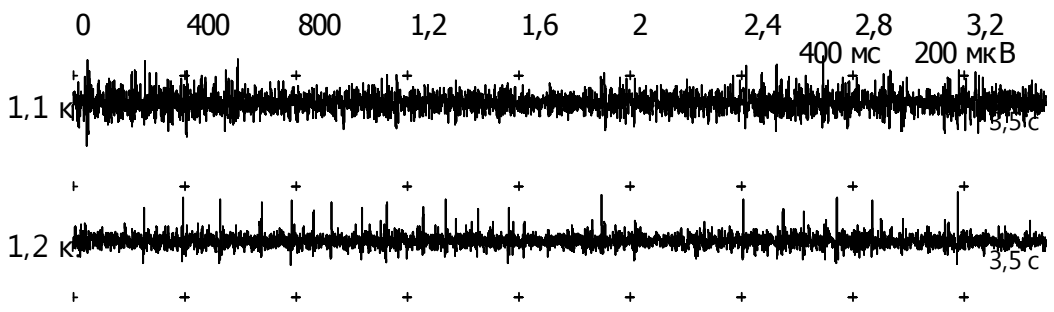

Рис. 2. Характер електронейроміографічної асиметрії у пацієнта з легким ступенем фіброміалгічного синдрому за розсіяного склерозу у поєднанні з функціональними порушеннями постави: 1,1 к: пр., Erector trunci (spinae), nn. Intercostales, $\mathrm{T}_{9}-\mathrm{T}_{12} ; 1,2$ к: лів., Erector trunci (spinae), nn. Intercostales, $\mathrm{T}_{9}-\mathrm{T}_{12}$ 


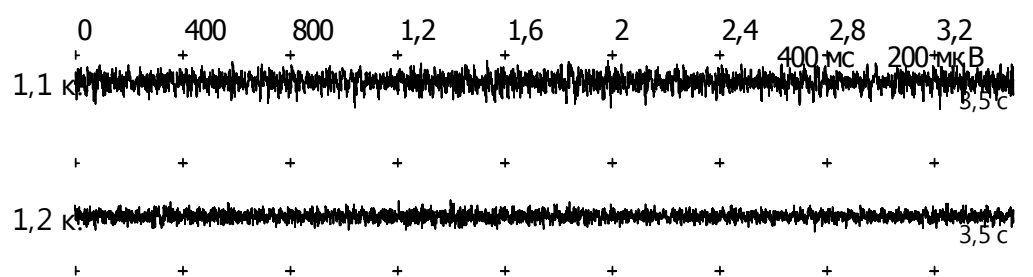

Рис. 3. Характер електронейроміографічної асиметрії у пацієнта із середнім ступенем фіброміалгічного синдрому за розсіяного склерозу у поєднанні з функціональними порушеннями постави: 1,1 к: пр., Erector trunci (spinae), nn. Intercostales, $\mathrm{T}_{9}-\mathrm{T}_{12} ; 1,2$ к: лів., Erector trunci (spinae), nn. Intercostales, $\mathrm{T}_{9}-\mathrm{T}_{12}$

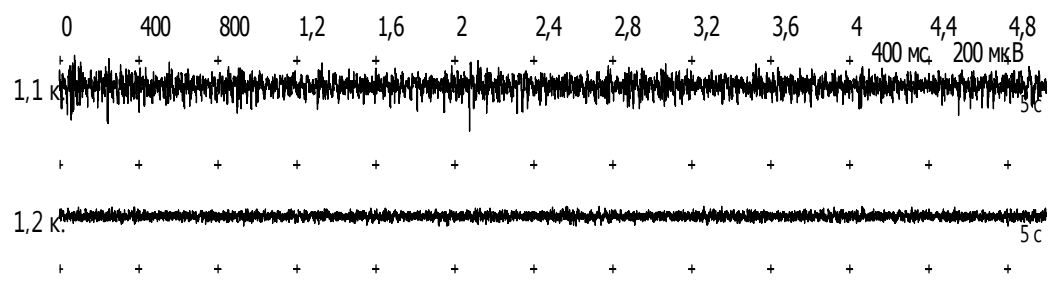

Рис. 4. Характер електронейроміографічної асиметрії у пацієнта з важким ступенем

фіброміалгічного синдрому за розсіяного склерозу у поєднанні з функціональними порушеннями постави:

1,1 к: пр., Erector trunci (spinae), nn. Intercostales, $\mathrm{T}_{9}-\mathrm{T}_{12} ; 1,2$ к: лів., Erector trunci (spinae), nn. Intercostales, $\mathrm{T}_{9}-\mathrm{T}_{12}$

\section{Обговорення}

Результати досліджень вказують на те, що розсіянний склероз часто супроводжується функціональними порушеннями постави. На цей факт інші автори мало звертали увагу, однак саме таке поєднання часто створює значні труднощі не тільки для діагностики, а й під час проведення реабілітаційних заходів, оскільки в цій ситуації, залежно від ступеня важкості перебігу основного захворювання, тригерні пункти часто можуть формуватися не тільки у м'язах, а й у зв'язках і фасціях (Colbert and Borg-Stein, 2016).

Дослідженнями Dommerholt and Bron (2013) встановлено, що ці анатомічні утворення володіють контрактильними властивостями, тому можуть брати участь у формуванні первинних або вторинних фасціально-зв'язкових тригерних локусів. Ми встановили, що первинні фасціально-зв'язкові тригерні пункти утворюються внаслідок локальної контрактильної властивості зв'язок без участі м'язів. Вторинні фасціально-зв'язкові тригерні пункти формуються в динамічних частинах м'язів (фасціях, апоневрозах тощо) і проявляються після утворення міогенного тригерного пункту. Обидва види фасціально-зв'язкових тригерних пунктів мають близький патогенетичний механізм, а за близькістю суб'єктивного прояву окремі автори об'єднують їх під назвою больового міофібрилярного синдрому (Partanen et al., 2010). Низкою досліджень (Hsieh, 2011) установлено, що тривало існуюючий міогенний і фасціально-зв'язковий гіпертонус спричиняє фіброзне переродження м'язової тканини. При цьому відомо (Buskila, 2010), що локальний, латентний м'язовий біль має місцевий прояв і виникає під час розтягування та місцевого натискання. За даними Wiles (2008), в останньому випадку біль може зникати після незначного розтягування.

Наші дані узгоджуються з результатами досліджень інших авторів (Partanen, 2010; Kanekar and Aruin, 2013), які вказують, що у цих людей нерідко спостерігається надлишкове поєднане залучення до скоротливої активності ближніх і віддалених агоністів, яке проявляється регіонарними м'язово-тонічними реакціями, що не мають пристосувального значення. На нашу думку, підвищена синергічна активність агоністів реципрокно створює вплив на антагоністи, формуючи патологічні координаційні комплекси. Це положення підтверджується у працях низки авторів (Gerwin, 2010), які вказують на прямо пропорційну залежність і прямий вплив супрасегментарних регуляторів рухових актів на рівень больових відчуттів у локальних м'язових ущільненнях.

Міофасціальний больовий синдром за розсіяного склерозу виникає у період гострої стадії захворювання, коли різко зростає спастичність і порушення рухових стереотипів (Daniels and Ishmael, 2010). Найчастіша локалізація тригерних точок у м'язах плечового поясу спостерігається у м'язах-ротаторах плечового суглоба, двоголовому м'язі плеча та верхній частині трапецієподібного м'яза. При цьому тригерні точки розташовуються як у самому м'язі, так і в м'язових сухожилках.

Установлений нами специфічний характер пропорційності розподілу потенціалу дії рухової одиниці $(50,0 \%$ - у зоні середньої тривалості та по 25,0\% - у зоні вкорочених і тривалих потенціалів) вказує на «залпову» електроміографічну активність під час поперечної пальпації м'язів, що відповідає локальній спастичній відповіді (Miller, 2013).

Із урахуванням теорії створення поліфункціональних систем організму потрібно зазначити, що будь-який біологічний пристосувальний результат (або руховий факт) являє собою універсальну форму саморегульованої системи. Тому під час порушення супрасегментарної взаємодії або сегментарних механізмів побудови локомоцій, які спостерігаються за розсіяного склерозу у поєднанні з функціональними порушеннями постави, руйнується негативний зворотний зв'язок. Це, у свою чергу, стає основою для розпаду поліфункціональної системи, оскільки відсутнє узгодження між параметрами конкретного результату дії та параметрами аферентного синтезу, який здійснюється акцептором за фізіологічних умов. Результат такого розладу між окремими частинами поліфункціональної системи різке зниження активності окремих частин опорно-рухового апарату під час забезпечення найпростіших і надійних характеристик локомоцій. Створюються патологічні умови для реалізації простих рефлекторних реакцій, підтримання гіпертонусу, порушення силових характеристик м'язів, реципрокних відносин, синергії та антагонізму цілих груп скелетних м'язів. Отже, за розсіяного склерозу у поєднанні з іншою патологією порушується сам програмний тип пошуку вибору та інтеграції різних виконавчих можливостей опорно-рухового апарату, що викликає формування неправильного рухового стереотипу в організмі таких хворих. Формується міофасціальний гіпертонус, який змінює програму реалізації рухового завдання щодо підтримання правильної фізіологічної постави.

Міофасціальний гіпертонус викликає електронейроміографічні зміни, зафіксовані нами у пацієнтів із таким патологічним поєднанням як розсіяний склероз і функціональні порушення постави та зміни за монопатології хребта чи поєднання «сколіоз і плоскостопість», показані у публікаціях інших автоpiв (Pandey et al., 2014). Різниця цих електронейроміографічних показників чітко вказує на супра- та сегментарний рівень порушень у хворих із розсіяним склерозом, що може бути використано для діагностики їх схильності до сколіозу чи поєднання сколіозу зі змінами склепінчастого апарату стопи. 
Цей факт потребує спеціального дослідження та буде являти для нас особливий інтерес у майбутній серії досліджень.

За поєднаної патології активний міофасціальний гіпертонус набуває властивостей генератора патологічно підсиленого збудження, що сприяє перетворенню негативного зворотного зв'язку на позитивний зв'язок. Це вказує на трансформацію фізіологічної функціональної системи на патологічну функціональну систему. Деякі автори (Kanekar and Aruin, 2013) вказують, що патологічна функціональна система побудована за принципом взаємодії позитивних зворотних зв'язків, а іiї стійкий патологічний стан підтримується активним станом у вигляді міофасціального гіпертонусу в аферентному синтезі виконавчих структур опорно-рухового апарату на різних рівнях організації. Тому відбувається десинхронізація в роботі фізіологічної функціональної системи внаслідок наростаючої детермінації патологічної активності. При цьому міофасціальному гіпертонусу відводиться особлива роль у появі додаткових зворотних позитивних зв'язків у програмі побудови системи локомоцій за розсіяного склерозу у поєднанні з порушеннями постави.

На наш погляд, різний ступінь прояву порушень постави може впливати на виявлену різницю електронейроміографічних показників у хворих із розсіяним склерозом. Тому, залежно від величини електронейроміографічних показників, ми виділили три стадії формування патологічної функціональної системи.

Перша стадія визначається дисфункцією корекційної побудови локомоцій і реалізується у вигляді локальних м'язових і фасціальних гіпертонусів тих груп м'язів, які розташовані на контрлатеральному боці від патологічного згину хребта.

На другій стадії змінюється стереотип рухів, з'являються тонічні порушення, пов'язані з порушенням постави. Вони проявляються у вигляді генералізованих, регіонарних, перехресних або пошарових синдромів.

Для третьої стадії характерне збільшення детермінації міофасціального гіпертонусу за рахунок участі супрасегментарних центрів вегетативної нервової системи, що проявляється індивідуальними порушеннями вегетативного тонусу, дестабілізацією сну, депресивними реакціями.

Потрібно зазначити, що формування розгорнутої клінічної картини психовегетативного синдрому за сколіозу - тривалий процес, а функціональний дефіцит протибольової системи сприяє формуванню фіброміалгічного компонента протягом не менше трьох місяців.

Із позиції теорії функціональних систем доцільно виділяти три ступені фіброміалгічного синдрому.

Легкий ступінь виражається активацією тригерних феноменів у вигляді локальної болючості, ущільненням і судомами у відповідь на міофасціальні гіпертонуси. При цьому кількість тригерних точок, їх розподіл у м'язах, фасціях і сухожиллях не мають принципового значення. 3'являються вкорочені та гіпотонічні («в'ялі») м'язи. Вегетативні порушення мають яскраво виражений характер у вигляді місцевої полімоторної реакції, пітливості, зниження електричного імпедансу шкіри тощо. На цій стадії спостерігаються синдроми переднього драбинчастого, грушоподібного, малого грудного, великого та малого заднього прямого м'язів голови тощо.

Середній ступінь: до вищезазначених змін приєднується порушення рухового стереотипу, а вторинний синдром вегетативної дисфункції може бути перманентним або пароксизмальним у формі астенії, звуження діапазону вегетативного реагування, перехресних синдромів, різкої зміни постави, зниження спритності під час виконання складних рухових комплексів. Зранку у пацієнтів реєструються скарги на тугорухомість і ломоту в усьому тілі, які минають після розминки.

Весь комплекс патологічної перебудови локомоторного стереотипу базується на різних рухових дефектах, які визначаються дисфункціями на рівні палідонігральної організації поліфункціональної системи.

Важкий ступінь характеризується сформованими перехресними синдромами. Такі пацієнти мають специфічний тип локомоторної організації, характеризуються незграбністю рухів, невмінням розслаблятися, вони погано навчаються гімнастичних вправ тощо. У них часто спостерігається виражений шийний гіперлордоз, сутулість, плечі припідняті та висуваються вперед, нерідко виявляється також поперековий гіперлордоз.

Враховуючи те, що один з основних проявів розсіяного склерозу - враження системи зорового аналізотора, а фіброміалгічний синдром вимагає застосування значного арсеналу медикаментозних засобів, які часто протипоказані саме за захворювань цього аналізатора, для компенсації невротичних, депресивних і вегетативних розладів необхідний, а іноді і єдиний засіб - методи фізичної реабілітації (Niraj, 2012).

\section{Висновки}

Міофасціальний гіпертонус 3 поєднанням розсіяного слерозу та функціональних порушень постави формується в три етапи: а) залишкова деформація м'язів за ізометричного виду роботи мінімальної інтенсивності та максимальної тривалості 3 патологічною перебудовою архітектоніки м'яза, що викликає спотворення пропріоцентивної активності з ділянки гіпертонусу; б) створення аферентації регуляторних релейних пунктів як сегментарного апарату спинного мозку (кільцево-корекційний тип локомоцій), так і супрасегментарних структур (програмний тип організації локомоторного акту) у центральній нервовій системі; в) перебудова нормального локомоторного стереотипу у патологічно сформований фібро-больовий синдром, який має латентний і активний тригерний феномен.

Різний ступінь порушення постави за розсіяного склерозу має типові клінічні та електронейрографічні прояви, патогномонічні з яких: а) наявність потенціалів занурення тривалістю понад 10 с (зміна гістограми розподілу потенціалів дії рухових одиниць за рахунок їх перекалібрування; б) збільшення кількості вкорочених і подовжених та зменшення середніх за тривалістю потенціалів; в) створення «залпової» електронейрографічної активності під час поперечної пальпації м'язів.

Міофібрилярний больовий комплекс - типовий патологічний сидром, характерний для поєднання розсіяного склерозу та функціональних порушень постави, а його ініціатор міофасціальний гіпертонус.

Перспективи подальших досліджень полягають у вивченні впливу засобів фізичної реабілітації на прояв фіброміалгічного синдрому в людей із розсіяним склерозом і схильністю до патології хребта або вираженим сколіозом із порушенням склепінчастого апарату стопи того чи іншого ступеня важкості.

\section{References}

Buskila, D. (2010). Fibromyalgia, chronic fatigue syndrome, and myofascial pain syndrome. Current Opinion in Orthopedics, 11(1), 49-55.

Colbert, M., \& Borg-Stein, J. (2016). Fibromyalgia, myofascial pain syndrome, and related conditions. Pathology and Intervention in Musculoskeletal Rehabilitation, 1164-1174.

Daniels, J. M., \& Ishmael, T. (2010). Managing myofascial pain syndrome. The Physician and Sports Medicine, 38(4), 39-45.

Dommerholt, J., \& Bron, C. (2013). Myofascial pain syndrome: Trigger points. Journal of Musculoskeletal Pain, 21(2), 183-195.

Gerwin, R. (2010). Myofascial pain syndrome: Here we are, where must we go? Journal of Musculoskeletal Pain, 18(4), 329-347.

Henriksson, K. G. (2013). Hypersensitivity in muscle pain syndromes. Current Pain and Headache Reports, 7(6), 426-432.

Hilz, M. J. (2016). Cardiac stunning as first manifestation of multiple sclerosis: A case report reminding us not-overlook cardiovascular autonomic dysfunction in multiples clerosis. Multiple Sclerosis Journal, 22(6), 847-848.

Hsieh, Y. L., Chou, L. W., Joe, Y. S., \& Hong, C. Z. (2011). Spinal cord mechanism involving the remote effects of dry needling on the irritability of myofascial trigger spots in rabbit skeletal muscle. Archives of Physical Medicine and Rehabilitation, 92, 1098-1105.

Hutchinson, M. (2013). The best clinical paper on multiple sclerosis in 2012: Commentary. Multiple Sclerosis Journal, 19(5), 522-523. 
Hutchinson, M. (2014). The best basic science paper in multiple sclerosis in 2013: Disease specific molecular events in cortical multiple sclerosis lesions. Multiple Sclerosis Journal, 20(14), 1817-1818.

Kanekar, N., \& Aruin, A. S. (2013). The role of clinical and instrumented outcome measures in balance control of individuals with multiple sclerosis. Multiple Sclerosis International, 20(13), 1-10.

Miller, A. E. (2013). The best clinical paper on multiple sclerosis in 2012. Multiple Sclerosis Journal, 19(5), 520-521.

Niraj, G. (2012). Ultrasound-guided pulsed radiofrequency treatment of myofascial pain syndrome: A case series. British Journal of Anaesthesia, 109(4), 645-646.

Pandey, K. S., Krieger, S. C., Farrell, C., Hannigan, C., DeAngelis, T., Miller, A. E., \& Lublin, F. D. (2014). Clinical course in multiple sclerosis patients presenting with a history of progressive disease. Multiple Sclerosis and Related Disorders, 3(1), 67-71.

Partanen, J. V., Tuula, A., Ojala, T. A., \& Arokoski, J. P. A. (2010). Myofascial syndrome and pain: A neurophysiological approach. Pathophysiology, 17(1), 19-28.

Roeing, K. L., Moon, Y., \& Sosnoff, J. J. (2017). Unplanned gait termination in individuals with multiple sclerosis. Gait and Posture, 53, 168-172.

Simons, D. G., \& Dommemolt, J. (2007) Myofascial pain syndromes trigger points. Journal of Musculoskeletal Pain, 15(2), 69-84.

Suputtitada, A. (2016). Myofascial pain syndrome and sensitization. Physical Medicine and Rehabilitation Research, 1(5), 1-4.

Wiles, C. (2008). Physiotherapy and related activities in multiple sclerosis. Multiple Sclerosis Journal, 14(7), 863-871. 